\title{
Van Wyntjie en tryntjie
}

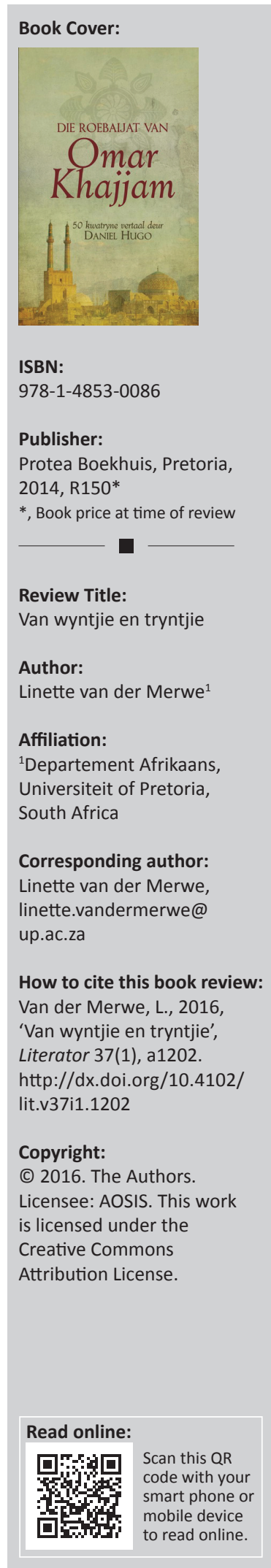

Omar Khajjam se Persiese kwatryne, Die roebaijat, word beskou as een van die bes verkoopte digbundels sedert die Engelse vertaling daarvan, deur Edward Fitzgerald (1809-1883), in 1859 verskyn het. Sedertdien het meer as 650 verskillende weergawes al die lig gesien en dien dit as inspirasie vir menige skrywer en komponis. Fitzgerald was 'n Engelse digter wat onder meer Persiese letterkunde aan Oxford bestudeer het. Vier uitgawes van sy Khajjam-vertaling het in sy leeftyd verskyn. Omar Khajjam was 'n Persiese sterrekundige, wiskundige, filosoof en digter. Hy is in 1048 in Naisjapoer, Noordoos-Iran gebore en in 1131 oorlede. Daar word beweer dat hy in sy lewe meer as 'n 1000 kwartyne of roebaijat (die Persiese woord vir kwatryn) geskryf het.

Benewens dié jongste vertaling van 50 van Khajjam se kwatryne in Afrikaans deur Daniel Hugo, wat hier ter sprake is, het daar al vyf Afrikaanse vertalings die lig gesien. Die roebaijat deur C.J. Langenhoven, wat in 1923 verskyn het, was die eerste. Na die vertaling van Langenhoven verskyn 'n weergawe van Herman Charles Bosman wat naam- en datumloos deur Colin ReedMcDonald in Kaapstad uitgegee is. Daarna het 16 van die kwatryne vertaal deur C. Louis Leipoldt in sy postume bundel Geseënde skaduwees in 1949 verskyn. Abraham Jonker se weergawe, Die onherwinbare hede, het in 1950 verskyn en in 1997 verskyn Rubáiyát van Omar Khayyám - 'n vertaling deur Sebastian Basson.

Vir hierdie bundel van Khajjam se kwatryne het Daniel Hugo 50 van die kwatryne, wat deur Edward Fitzgerald vertaal is, uitgesoek op grond van hul vertaalbaarheid en trefkrag in Afrikaans (bl. 15). Hugo beklemtoon in die inleidende toeligting van die bundel (bl. 7) dat Fitzgerald se vertalings in ' $n$ groot mate as herskrywings beskou moet word. Hy verklaar verder ook dat hy sover moontlik die Persiese kwatryn se aaba-rympatroon en die tienlettergrepige versreëllengte probeer handhaaf het (bl. 14-15).

Khajjam se hedonistiese lewensfilosofie word tematies, skertsend, bondig en beeldend in Persiese kwatryne verwoord. Die oordadige liefde vir eet, wyn, vroue en woeker met die liefde, want die môre sterf ons, word deur Hugo (bl. 11) soos volg vertaal:

\footnotetext{
Here with a Loaf of Bread beneath the Bough,

A Flask of Wine, a Book of Verse - and Thou

Beside me singing in the Wilderness -

And Wilderness is Paradise enow.

Met 'n verseboek in die skaduwee,

'n bottel wyn, 'n brood en jy daarmee

saam om vir my te sing in die woestyn -

en woestyn word 'n paradys vir twee.
}

Khajjam beklemtoon in die meerderheid van die verse dat die mens die lewe moet aangryp voordat dit te laat is, soos dit onder andere spreek uit Kwatryn 14, waar die allitererende s-klank ook die mens se verganklikheid beklemtoon:

\footnotetext{
Ah, make the most of what we yet may spend,

Before we too into Dust descend;

Dust into Dust, and under Dust, to lie,

Sans Wine, sans Song, sans Singer and - sans End!
}

Geniet die lewe sonder perk of paal,

Voordat jy asvaal in die stof afdaal.

Stof tot stof en onder stof sal jy lê,

sonder wyn en sonder sang - dis finaal! 
Ook die mens se onvermoë om die lewe en die grootsheid van die Skepping te begryp kom as eksistensiële vrae aan die bod:

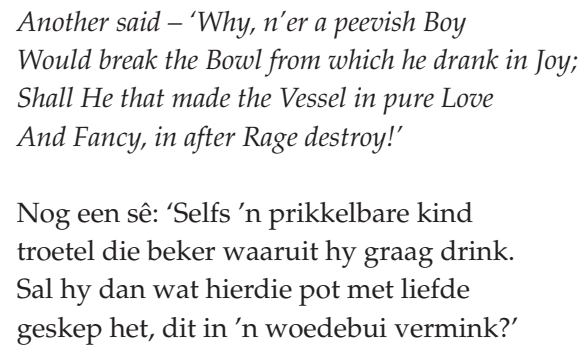

Nog een sê: 'Selfs 'n prikkelbare kind troetel die beker waaruit hy graag drink. Sal hy dan wat hierdie pot met liefde geskep het, dit in 'n woedebui vermink?'

Uit die bostaande, aangehaalde, vertaalde verse blyk veral dat dit van uiterste belang is dat lesers van hierdie bundel deurlopend in gedagte hou dat die vertaling van poësie 'n uiters komplekse saak is. Die vertaler van gedigte moet deurentyd rekening hou met tegniese aspekte soos versbou, beeldspraak, klankwaardes, rym, halfrym en ritme, en in die geval van die Roebaijat, ook met die vereiste eindrym in die eerste, tweede en vierde versreël van elke kwatryn. Hugo bly getrou aan die teksinhoud en al is daar soms ritmiese steurings, bied die speelsheid van, en die wyshede in die verse heelwat stof tot nadenke.

Daniel Hugo word nie sonder rede as digter-vertaler beskou nie. In 2014 ontvang hy die Suid-Afrikaanse Akademieprys vir sy vertaling van die Vlaming Tom Lanoye se roman Sprakeloos. Die vertaling van die Roebaijat bevestig sy vernuf as vertaler en ook as digter wat kreatief met die teks kan omgaan en al die skakerings en verhulde betekenisse van die Fitzgerald-vertaling suksesvol in Afrikaans kan transponeer.

Die roebaijat van Omar Khajjam (2014) behoort 'n ereplek op alle lesers van Afrikaanse poësie se boekrakke te kry. Nie net is dit is beknopte bundel vol lewenswyshede nie, maar 'n uitstalvenster vir vernuftige vierreëlige verskuns:

Toe ek jonk was, het ek graag gaan luister hoe dokter en dominee oor duister

dinge redeneer. Nou is ek grys en die ware weg altyd byster. 